\title{
Correction to: Role of membrane glycerolipids in photosynthesis, thylakoid biogenesis and chloroplast development
}

\section{Koichi Kobayashi ${ }^{1}$}

Published online: 21 February 2018

(c) The Author(s) 2018. This article is an open access publication duplication, adaptation, distribution and reproduction in any medium or format, as long as you give appropriate credit to the original author(s) and the source, provide a link to the Creative Commons license, and indicate if changes were made.

Open Access This article is distributed under the terms of the Creative Commons Attribution 4.0 International License (http://creativeco mmons.org/licenses/by/4.0/), which permits unrestricted use, distribution, and reproduction in any medium, provided you give appropriate credit to the original author(s) and the source, provide a link to the Creative Commons license, and indicate if changes were made.
The original article can be found online at https://doi.org/10.1007/ s10265-016-0827-y.

Koichi Kobayashi

kkobayashi@bio.c.u-tokyo.ac.jp

1 Department of Life Sciences, Graduate School of Arts and Sciences, The University of Tokyo, Komaba 3-8-1, Meguro-ku, Tokyo 153-8902, Japan 